\title{
Erdei orchideák és föld alatti gombák felvételezése és együttes előfordulásának vizsgálata a Kárpát-medence területén
}

\author{
Bóna Lilla ${ }^{1}$, Merényi Zsolt ${ }^{2}$ és Bratek Zoltán ${ }^{1}$ \\ ${ }^{1}$ Eötvös Lóránd Tudományegyetem, Természettudományi Kar, Növényélettani és \\ Molekuláris Növénybiológiai Tanszék \\ 1117 Budapest, Pázmány Péter sétány $1 / C$. \\ ${ }^{2}$ Magyar Tudományos Akadémia Szegedi Biológiai Kutatóközpontja, Biokémiai Intézet, \\ Szintetikus és Rendszerbiológiai Egység, \\ 6726 Szeged, Temesvári krt. 62. \\ e-mail:bonalillaaa@gmail.com
}

\begin{abstract}
Összefoglaló: Az Orchidaceae család veszélyeztetett fajokban bővelkedik, emiatt természetvédelmi szempontból jelentős. Továbbá tagjai számos élőlénnyel élnek szoros kapcsolatban, így a természetvédelem feladata mind a szimbionta organizmusok, mind az orchideák élőhelyeinek védelme. Munkánk során hazai erdei orchideák és föld alatt termőtestet képző gombák egy élöhelyen történő előfordulásának összefüggéseit vizsgáltuk, ugyanis terepi tapasztalataink alapján ezek az élőlények gyakran egy élettérben találhatók. Az együttes előfordulást gyakorisági és együtt-előfordulási („,cooccurence") vizsgálatokkal végeztük. Eredményeink alapján, erdei orchideás élőhelyeken leggyakrabban a valódi szarvasgombák (Tuber spp.), azon belül a nyári szarvasgomba (Tuber aestivum) fordul elő a vizsgált föld alatti gombák közül, míg a „co-occurence” vizsgálatok hat orchidea-föld alatti gombafaj együttes előfordulásának pozitív kapcsolatát mutatták. Az egy élőhelyen történő előfordulás felhívja a figyelmet a törvényileg elöírt szarvasgomba gyüjtési szabályok betartásának a fontosságára, mellyel az orchideák védelme mellett a talajt behálózó gomba micélium védelme is valóra válhat.
\end{abstract}

Kulcsszavak: orchidea, föld alatti gomba, orchid mikorrhiza, együttes előfordulás

\section{Bevezetés}

Az orchideafélék családja a legnagyobb fajszámmal rendelkező család a zárvatermő növények körében, mely fajszám 25.000-27.000-re tehető (Dearnaley 2007). Az orchideák biológiai és természetvédelmi szempontból is kiemelkedő jelentőséggel bírnak, ezt a nagy fajszám mellett az is indokolja, hogy a család a Föld legveszélyeztetettebb fajai közül (pl. papucs orchideák) többet is tartalmaz 
(Fay 2016), ráadásul számos élőlénnyel állnak kapcsolatban (pl. pollinátorok, mikorrhiza-gombák, emberek) (Bulpitt 2005, Ghorbani et al. 2014). Ez életciklusukat sérülékennyé teheti, így a természetvédelmi szempontú kezeléseknél ezeknek a kapcsolatoknak a vizsgálata is elengedhetetlen lenne.

Az orchideák egyik legjelentősebb szimbiotikus kapcsolata különböző gombákkal képzett orchid típusú mikorrhiza, mely egy speciális endomikorrhiza (Smith \& Read 2010). E szimbiózis kezdeti szakaszának egyedisége abban rejlik, hogy az apró, néhány $\mu g$-os, tápanyagok (szénforrás, vitaminok, növekedési faktorok) nélküli orchidea mag kizárólag szimbionta gombapartnerei jelenlétében képes a csírázásra (Rassmussen, 1995; Bratek et al. 2001). A kifejlett orchidea növény gombapartnertől való függése szoros kapcsolatot mutat fotoszintetikus képességeivel (Bidartondo et al. 2004): a fotoszintetizáló orchideák esetében a kifejlett növénynek inkább csak a korai életszakaszaiban van szüksége a gombapartnertől kapott széntáplálásra (pl: madársisak - Cephalanthera fajok); részleges mikoheterotrófoknak a redukált levéllel és fotoszintetikus apparátussal rendelkező, illetve árnyékban élő fajokat nevezzük, melyek részben, még kifejletten is, függnek a gombáktól kapott szénhidrátoktól (pl: kislevelü nőszőfü - Epipactis microphylla); az obligát mikoheterotróf fajok pedig csekély mennyiségü zöld színanyaggal rendelkeznek vagy fotoszintetikus apparátusuk redukált, így kizárólag a gombapartner jelenlétében életképesek (pl. madárfészek kosbor - Neottia nidus-avis). Orchidea gyökerekből ezidáig számos gombataxon került kimutatásra, leggyakrabban a Rhizoctonia-forma nemzetség közül valók (Ouanphanivanh et al. 2007), azonban föld feletti (pl. Russula spp., Cortinarius spp., Inocybe spp., Hebeloma spp., Lactarius spp.) (Bidartondo et al. 2004; Pecoraro et al. 2006; Roy et al. 2009) és föld alatti (pl. Tuber aestivum, T. excavatum, T. maculatum) (Selosse et al. 2004, Ouanphanivanh et al. 2008) ektomikorrhiza-képző gombák is kimutatásra kerültek, így összekötve az orchideákat a környező ektomikorrhizát képző, fás szárú növényekkel. Terepi megfigyeléseink alapján gyakran fordulnak elő orchideás élőhelyeken föld alatt termőtestet képző gombataxonok. Jelen munkánk célja az volt, hogy képet adjon megfelelő statisztikai módszerek alkalmazásával az erdei orchideák és föld alatti gombák együttes előfordulásáról. A fajok együttes előfordulási vizsgálataira ma már egyre kifinomultabb statisztikai módszerek állnak rendelkezésre (Veech 2014). A „co-occurence” egy valószínüségi modell, mely megadja, hogy a két kiválasztott faj együtt kisebb vagy nagyobb gyakorisággal fordul elö, mint a fajonként megfigyelt független gyakoriságok (Veech 2013).

Magyarországon az összes természetben előforduló orchidea faj törvény által védett, közülük 16 fokozottan védett, továbbá a föld alatti termőtesttel rendelkező 
gombafajok közül is ismertek védettek (Elaphomyces sp.), mellyel megerősítendő a kiemelkedő természetvédelmi jelentőség.

\section{Módszerek}

A vizsgálatba vont orchidea taxonok

Munkánk során a következő, a Kárpát-medence területén előforduló orchidea taxonokat vizsgáltuk: nőszőfü nemzetség (Epipactis spp.), mely 19 hazai fajt tartalmaz; madársisak nemzetség (Cephalanthera spp.) mely három hazai fajt tartalmaz (Molnár et al. 2011); madárfészek kosbor faj (Neottia nidus-avis L. Rich 1817). A fenti orchidea taxonok kiválasztásának okai: hazánkban gyakran előfordulnak; mindhárom életmódot képviselik (ld. bevezetés).

\section{A terepi munka menete}

Harminc évet átfogó terepi munkáink során föld alatti gombák gyüjtését végeztük többnyire triflavadászebek segítségével. Ahol előfordult valamely föld alatti gomba taxon, a fészek köré kijelöltünk egy 10×10 méteres kvadrátot, melyben részletes botanikai felvételezést végeztünk, az adatokat a Kárpát-medence föld alatti gombafajainak biogeográfiai és ökológiai kutatására szolgáló számítógépes adatbázisunkba rögzítettük (Merényi et al. 2010). Terepi vizsgálataink kibővítéseként, 2013-ban Molnár V. Attila és kutatócsoportja (Debreceni Egyetem) által összegyüjtött lista alapján célzottan kerestük fel ültetett nyarasok orchideás élőhelyeit.

Az adatok feldolgozása

Az adatok összesítése után a gyakorisági értékek lettek kiszámolva az összes élöhelyen történő előfordulás bevonásával. A „,co-occurence” vizsgálatokat az R statisztikai program (R core team 2013) „Cooccur” programcsomagjával végeztük el az összes élőhely és a hegyvidéki gyertyános-tölgyes (Carici pilosae-Carpinetum) társulás esetén, mely a leggyakoribb társulás volt vizsgálatainkban.

\section{Eredmények}

Terepi munkáink során összesen 774 orchideás élöhelyet vizsgáltunk meg. Az összes felvételezésen 194 orchidea előfordulást detektáltunk, melyből a Cephalanthera nemzetség fordult elő leggyakrabban (92 felvétel), ezt követte az Epipactis nemzetség (65 felvétel), majd a Neottia nidus-avis (37 felvétel). A Cephalanthera nemzetségből leggyakrabban a Cephalanthera damasonium (60 
felvétel) fordult elö, majd azt követte a C. longifolia (24 felvétel), végül a C. rubra (8 felvétel). Az Epipactis nemzetségböl leggyakrabban az Epipactis helleborine Cr. s.str. került elö (44 felvétel), majd ezt követte az Epipactis atrorubens (7 felvétel), az Epipactis microphylla (5 felvétel), az Epipactis purpurata (4 felvétel), az Epipactis helleborine aggr. (3 felvétel), majd az Epipactis helleborine $\mathrm{Cr}$. subsp. viridis és az Epipactis muelleri (1-1 felvétel). Az adott gombanemzetségek kvadrátjában előforduló orchidea fajok/nemzetségek felvételeinek számát az 1. táblázat foglalja össze.

A gombanemzetségek és orchidea nemzetségek együttes előfordulásának gyakorisági adatait a 2. táblázat foglalja össze. Az általunk vizsgált 774 orchideás élőhelyen összesen 1079, számos nemzetségbe tartozó föld alatti gomba felvételezését végeztük. Legnagyobb számban a Tuber nemzetség tagjai képviseltették magukat (699 felvétel), ezt követte a Hymnogaster (125 felvétel), majd az Elaphomyces nemzetség (78 felvétel). Az Epipactis nemzetség felvételeinek 69\%a fordult elő egy élőhelyen a Tuber nemzetséggel, a Cephalanthera nemzetség 67\%-a, a Neottia nidus-avis 54\%-a. A Tuber nemzetség esetében a felvételek 9\%ában fordult elö valamelyik Epipactis faj, 6\%-ában Cephalanthera és 3\%-ában a Neottia nidus-avis. A Hymenogaster nemzetség esetében a felvételek 2-11\%-ban fordult elö valamely orchidea nemzetség, az Elaphomyces esetén 1-4\%-ban, ezek az előfordulások az adott orchidea nemzetségek 8-15\%-át (Hymenogaster), illetve 1-5\%-át (Elaphomyces) teszik ki. Kiemelendő még a Genea nemzetség és a Neottia-nidus avis együttes előfordulásának adatai, ahol a felvételek 11\%-ában fordult elő ez az orchidea faj, ami az összes Neottia felvételnek a 16\%-a volt. A többi gombataxonhoz detektált orchidea felvételezések az alacsony találati szám miatt nem kerülnek értékelésre.

A gyakoribb gombafajok és az orchidea nemzetségek együttes előfordulásának gyakorisági adatait a 3. táblázat foglalja össze. A Tuber nemzetség leggyakoribb faja orchideás élöhelyeken a $T$. aestivum (193 felvétel), mely faj az általunk detektált Cephalanthera felvételezések 31\%-ában, az Epipactis felvételezések 39\%ában, míg a Neottia 13\%-ában fordult elö. A T. aestivum a 193 elöfordulásával szignifikánsan nagyobb arányban fordult elő azokon az élőhelyeken, ahol orchideát is detektáltunk, mint amit az összes élőhelyen felvételezett előforduláshoz viszonyítva várnánk (Fisher-féle egzakt teszt, $\mathrm{p}<0,0001$ ), ugyanis 1079 felvételen 193 T. aestivum detektálását végeztük, ehhez viszonyítva 194 orchideás élőhelyen 34,7 a várt T.aestivum előfordulás, ennek ellenére 71 valós felvételünk volt. A $T$. aestivum felvételezéseket a T. rufum (138 felvétel), majd a T. brumale (99 felvétel) követte. A Hymenogaster nemzetség leggyakoribb fajai orchideák mellett a $H$. griseus (33 felvétel), H. citrinus (24 felvétel), H. luteus (21 felvétel) voltak. 10\% feletti gyakorisági értékek (az adott orchidea nemzetségek összes 
1. táblázat: Orchidea taxonok felvételezésének adatai. A táblázat adott föld alatti gomba nemzetségekkel egy kvadrátban lévő orchidea fajok számát mutatja be. Emellett az egyes orchidea nemzetségeket is összesíti az adott gombanemzetségekhez (12-14. oszlop). A táblázatban az is látható, hogy az adott orchidea fajból/nemzetségből összesen hány felvételezésünk volt (végösszeg - utolsó sor) és az is, hogy adott gombanemzetség mellett összesen hány orchidea felvételezésünk volt (végösszeg - utolsó oszlop). Az adott gombanemzetség után zárójelben az látható, hogy az melyik gombatörzshöz tartozik (Z-Zygomycota, G-Glomeromycota, A-Ascomycota, B-Basidiomycota).

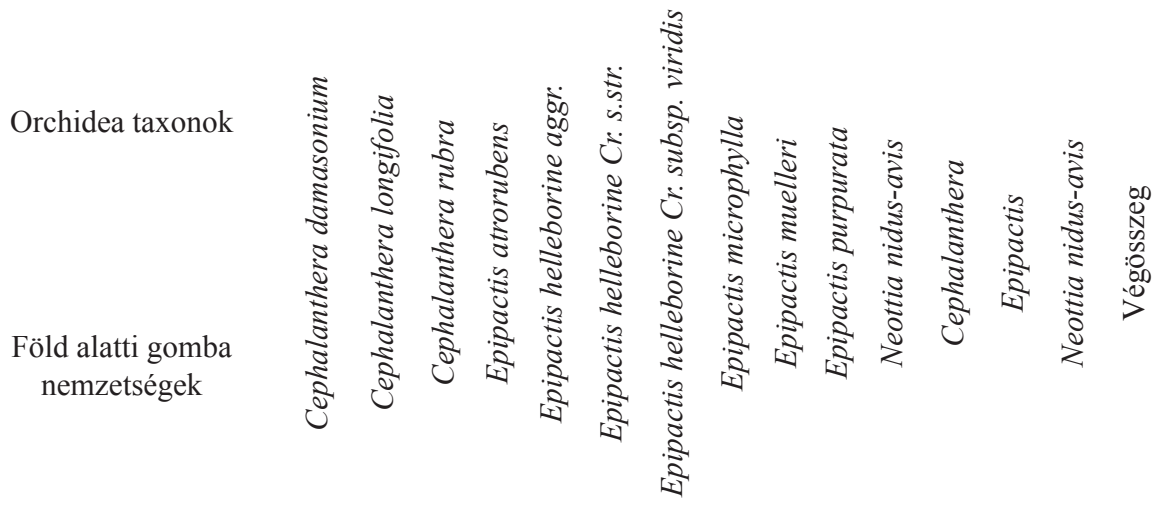

\begin{tabular}{lccccccccccccccc}
\hline Arcangeliella (B) & 0 & 0 & 0 & 0 & 0 & 2 & 0 & 0 & 0 & 0 & 0 & 0 & 2 & 0 & 2 \\
Choiromyces (A) & 0 & 3 & 0 & 0 & 0 & 1 & 0 & 0 & 0 & 0 & 0 & 3 & 1 & 0 & 4 \\
Elaphomyces (A) & 1 & 0 & 0 & 0 & 0 & 2 & 0 & 1 & 0 & 0 & 2 & 1 & 3 & 2 & 6 \\
Endogone (Z) & 0 & 0 & 0 & 0 & 0 & 0 & 0 & 0 & 0 & 0 & 1 & 0 & 0 & 1 & 1 \\
Gautieria (B) & 0 & 0 & 0 & 0 & 0 & 0 & 0 & 0 & 0 & 0 & 1 & 0 & 0 & 1 & 1 \\
Genea (A) & 2 & 0 & 0 & 1 & 0 & 2 & 0 & 0 & 0 & 0 & 6 & 2 & 3 & 6 & 11 \\
Glomus (G) & 0 & 1 & 0 & 0 & 0 & 0 & 0 & 0 & 0 & 0 & 0 & 1 & 0 & 0 & 1 \\
Hydnobolites (A) & 2 & 0 & 0 & 0 & 0 & 0 & 0 & 0 & 0 & 0 & 0 & 2 & 0 & 0 & 2 \\
Hydnotrya (A) & 0 & 0 & 0 & 0 & 0 & 0 & 0 & 0 & 0 & 0 & 2 & 0 & 0 & 2 & 2 \\
Hymenogaster (B) & 12 & 2 & 0 & 1 & 0 & 8 & 0 & 0 & 0 & 0 & 3 & 14 & 9 & 3 & 26 \\
Hysterangium (B) & 0 & 0 & 0 & 0 & 0 & 0 & 0 & 0 & 0 & 0 & 1 & 0 & 0 & 1 & 1 \\
Melanogaster (B) & 1 & 0 & 0 & 0 & 0 & 0 & 0 & 0 & 0 & 0 & 1 & 1 & 0 & 1 & 2 \\
Octavianina (B) & 1 & 1 & 0 & 0 & 0 & 0 & 0 & 0 & 0 & 0 & 0 & 2 & 0 & 0 & 2 \\
Rhizopogon (B) & 0 & 0 & 0 & 0 & 0 & 1 & 0 & 0 & 0 & 0 & 0 & 0 & 1 & 0 & 1 \\
Sclerogaster (B) & 0 & 0 & 0 & 0 & 0 & 1 & 0 & 0 & 0 & 0 & 0 & 0 & 1 & 0 & 1 \\
Stephensia (A) & 1 & 1 & 1 & 0 & 0 & 0 & 0 & 0 & 0 & 0 & 0 & 3 & 0 & 0 & 3 \\
Tuber (A) & 39 & 16 & 7 & 5 & 3 & 27 & 1 & 4 & 1 & 4 & 20 & 62 & 45 & 20 & 127 \\
Zelleromyces (B) & 1 & 0 & 0 & 0 & 0 & 0 & 0 & 0 & 0 & 0 & 0 & 1 & 0 & 0 & 1 \\
Végösszeg & 60 & 24 & 8 & 7 & 3 & 44 & 1 & 5 & 1 & 4 & 37 & 92 & 65 & 37 & 194
\end{tabular}




\begin{tabular}{|c|c|c|c|c|c|c|c|}
\hline בี & ถิวzssọอิว & 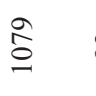 & สू & 6 & $\hat{n}$ & & \\
\hline 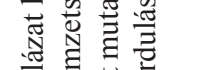 & $\operatorname{roqn}_{L}$ & જે & तु & $\stackrel{\wp}{+}$ & ㄱ. & वें ठें के & 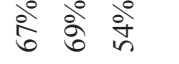 \\
\hline 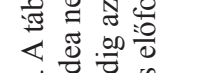 & 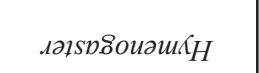 & $\cong$ & $\Xi$ & $a$ & $m$ & $\stackrel{\circ}{ٍ} \stackrel{0}{\circ} \stackrel{\circ}{ }$ & 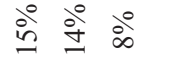 \\
\hline 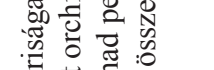 & səљКиочdp]马 & $\infty$ & - & $m$ & $\mathrm{~N}$ & $\stackrel{\circ}{\circ} \stackrel{\circ}{\circ} \stackrel{\circ}{ }$ & 을 in in \\
\hline 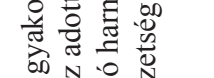 & рәиวฺ & in & $N$ & $m$ & 6 & 워 & ें in \\
\hline 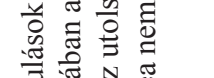 & 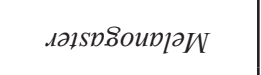 & i & - & 0 & - & $\stackrel{\circ}{+} \stackrel{\circ}{\circ}$ & ㅇ वे \\
\hline 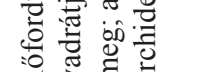 & รәљкиолючว & 9 & m & - & 0 & i̊ in & ஓे ஃे ठे \\
\hline 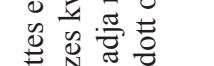 & ип!ฺириаұs $\varsigma_{H}$ & $\Xi$ & 0 & 0 & - & $\stackrel{\circ}{0} \stackrel{\circ}{\circ}$ & ठे ठे \\
\hline 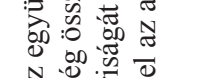 & р!sидуdәтS & $\cong$ & $m$ & 0 & 0 & तें & ஓें \\
\hline 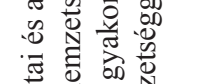 & иоводоz!чу & 으 & 0 & - & o & தீ & ठ̊ \\
\hline 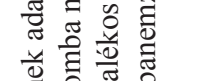 & ркиоорк & $r$ & 0 & 0 & N & தீ தீ ఏें & ठ̊ \\
\hline 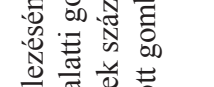 & sət!1oqoup $\kappa_{H}$ & $r$ & N & 0 & 0 & ลें & ํํ ठ̊ ठ̊ \\
\hline 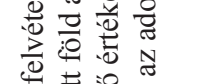 & 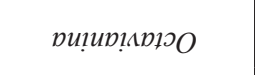 & in & $\sim$ & 0 & 0 & oे & ڤें \\
\hline 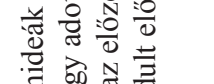 & snuоl: & $n$ & - & 0 & 0 & ठें & $\stackrel{\circ}{\circ} \dot{0}^{\circ}$ \\
\hline 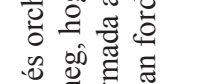 & sәэКиояәџวZ & $\nabla$ & - & 0 & 0 & iें & 용 \\
\hline 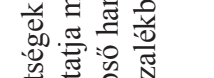 & 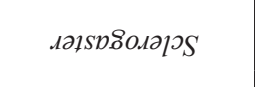 & + & 0 & - & 0 & 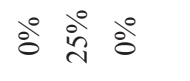 & ठ̊ \\
\hline 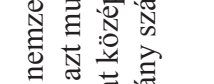 & 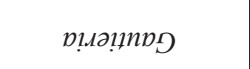 & n & 0 & 0 & - & ठ̊ ठे & 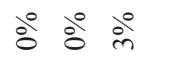 \\
\hline 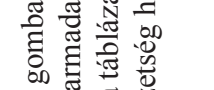 & әиовория & n & o & 0 & - & ठे 80 ले & ठे \\
\hline 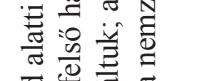 & 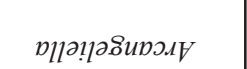 & $m$ & 0 & $\sim$ & o & \&̊ㅇํ & தे \\
\hline 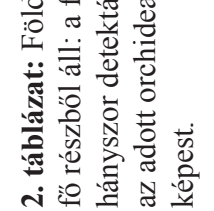 & 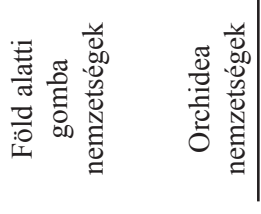 & 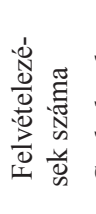 & 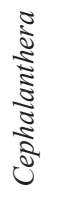 & 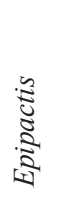 & 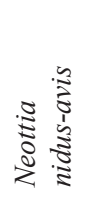 & 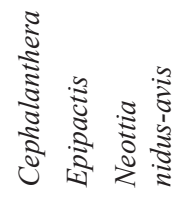 & 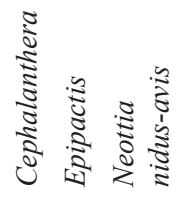 \\
\hline
\end{tabular}


előfordulásához viszonyítva - 3. táblázat 3. harmada) a következő pároknál figyelhetök meg: Tuber brumale/Neottia (20\%), a Tuber excavatum/Neottia (13\%), a Tuber rufum aggr./Cephalanthera (17\%) Tuber rufum aggr./Epipactis (13\%), Genea verrucosa/Neottia (11\%). 10\% feletti gyakorisági értékek (a legalább 20 találattal rendelkező gombafajok összes előfordulásához viszonyítva - 3. táblázat 2. harmada) a következö pároknál figyelhetök meg: T. aestivum/Cephalanthera (18\%), T. aestivum/Epipactis (16\%), T. excavatum/Cephalanthera (12\%), T. rufum aggr./Cephalanthera (14\%), Hymenogaster citrinus/Cephalanthera (21\%), Hymenogaster citrinus/Epipactis (13\%), Hymenogaster griseus/Epipactis (12\%), Hymenogaster luteus/Cephalanthra (19\%), Hymenogaster luteus/Epipactis $(10 \%)$, Genea verrucosa/Neottia (19\%).

A „co-occurence” vizsgálatok eredményeit az 1. ábra foglalja össze. A 774 élőhely bevonásával készült vizsgálat alapján pozitív föld alatti gomba/orchidea együttes előfordulást a Hymenogaster citrinus/Cephalanthera, a Tuber aestivum/Cephalanthera, a Genea verrucosa/Neottia, a Tuber brumale/Neottia, Hymenogaster griseus/Epipactis és a Tuber aestivum/Epipactis mutatott. Együtt elő-nem-fordulást az Elaphomyces muricatus/Cephalanthera, Tuber rufum/Neottia, Tuber brumale/Epipactis, Tuber macrosporum/Epipactis és az Elaphomyces muricatus/Epipactis gombafajok és orchidea nemzetségek mutattak. A hegyvidéki gyertyános-tölgyes (Carici pilosae-Carpinetum) társulások élőhelyeit kiválasztva (mely a leggyakoribb társulás volt vizsgálatainkban) a következő eredményeket kaptuk: 162 hegyvidéki gyertyános-tölgyes élőhely bevonásával pozitív gomba-orchidea együttes előfordulást a Tuber aestivum/Epipactis és a Genea verrucosa/Neottia mutattak, negatív együttes elöfordulást nem tapasztaltunk.

\section{Értékelés}

Az orchideákkal napjainkban is számos fórum foglalkozik, dísznövény értékük mellett természetvédelmi szempontból is igen jelentősek. Természetes élőhelyeiken tapasztalt megfogyatkozásuk okaként számos tényezőt tesznek felelőssé (pl. klimatikus viszonyok drasztikus változása, élőhely vesztés, élőhely fragmentáció, pollinátorok hiánya stb.) (Seaton et al. 2010). A természetvédelmi kezeléseknél ezért kiemelt feladat a növények ismeretén túl élőhelyük tanulmányozása és a növények biológiai szempontú vizsgálata is, vagyis a velük szimbiózisban álló élőlények kutatása. Jelen dolgozat a hazai erdei orchideák és föld alatti gombák egy élőhelyen történő előfordulásnak az összefüggéseit vizsgálja. Eredményei alapot 


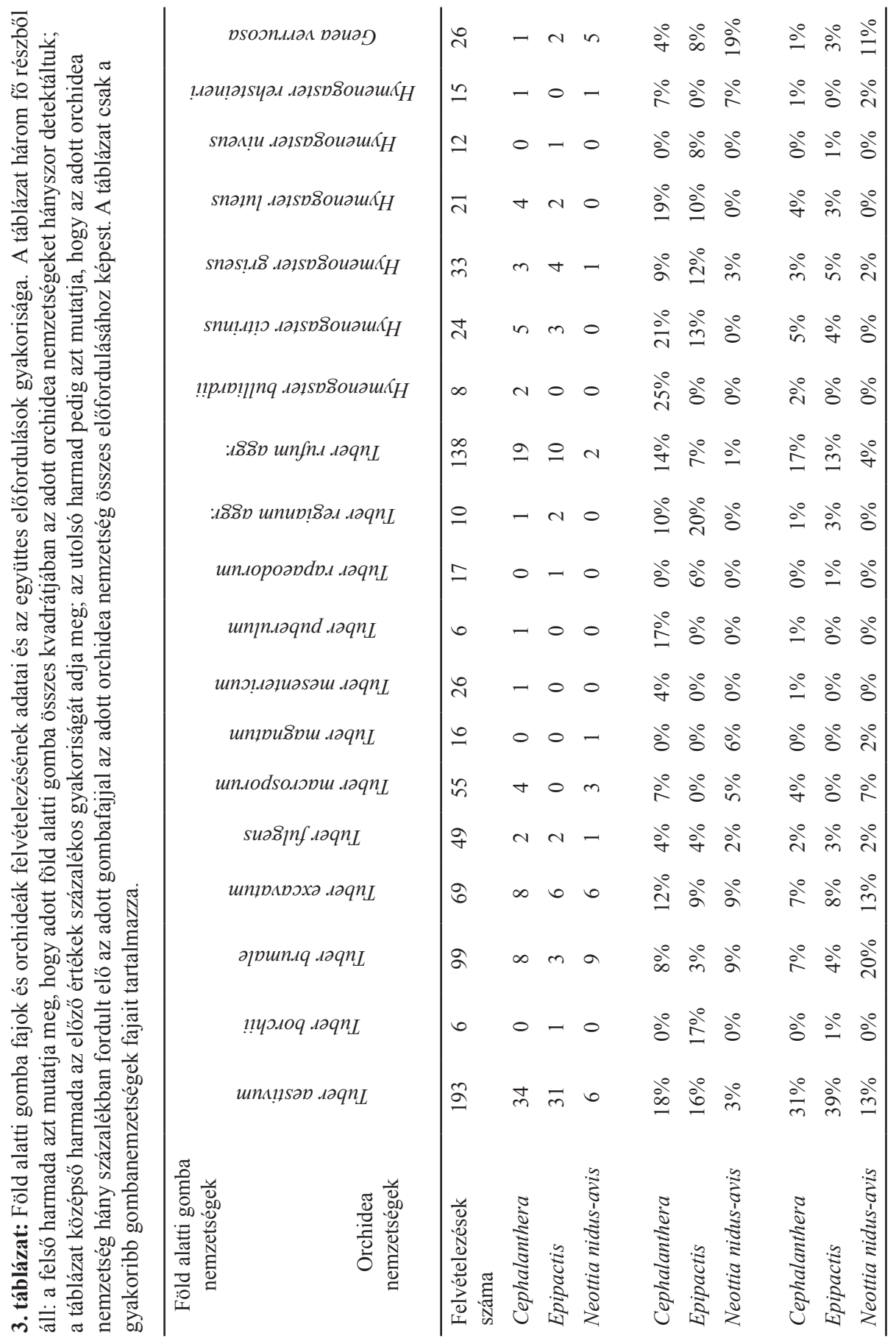




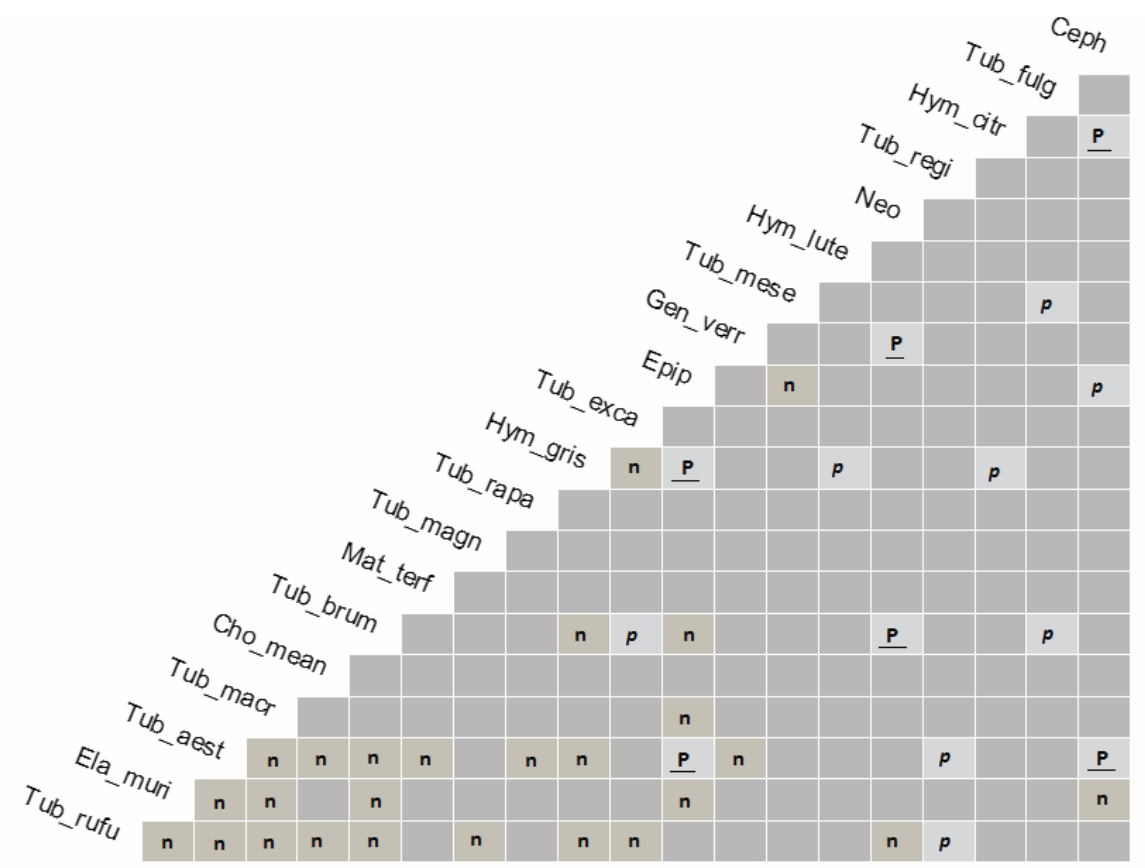

1. ábra: A „,co-occurence” vizsgálatok eredményei alapján készült mátrix. A mátrix az összes (774 darab) élőhely adatait dolgozza fel, minden egyes négyzet két-két taxon együttes előfordulását mutatja. Jelölések: n: negatív kapcsolat, p: pozitív kapcsolat, $\underline{P}$ : pozitív kapcsolat valamely orchidea és föld alatti gomba taxon között. Az üres négyzetek a véletlenszerü együttes előfordulást jelölik. Rövidítések: Tub_rufu: Tuber rufum; Ela_muri: Elaphomyces muricatus; Tub_aest:

Tuber aestivum; Tub_macr: Tuber macrosporum; Cho_mean: Choiromyces meandriformis; Tub_brum: Tuber brumale; Mat_terf: Mattirolomyces terfezioides; Tub_magn: Tuber magnatum; Tub_rapa: Tuber rapaeodorum; Hym_gris: Hymenogaster griseus; Tub_exca: Tuber excavatum; Epip: Epipactis spp.; Gen_verr: Genea verrucosa; Tub_mese: Tuber mesentericum; Hym_lut:

Hymenogaster luteus; Neo: Neottia nidus-avis; Tub_regi: Tuber regianum; Hym_citr: Hymenogaster citrinus; Tub_fulg: Tuber fulgens; Ceph: Cephalanthera spp.

adhatnak a további élőhelyi és mikorrhiza-partner vizsgálatokhoz, segítve ezzel a későbbi, orchideákra vonatkozó természetvédelmi tevékenységeket.

Az eredményeink alapján kapott gyakorisági vizsgálatok azt mutatják, hogy az összes orchideás élőhelyen (olyan élőhelyek is ide tartoznak, ahol orchideát nem detektáltunk terepi vizsgálataink során, de ismert orchideás élőhely), mind az olyan élőhelyeken, ahol orchidea ténylegesen előfordult leggyakrabban a gasztronómiai és gazdasági szempontból értékes fajokat is tartalmazó Tuber nemzetség fordult elő. A Tuber nemzetséget a gasztronómiai jelentőséggel nem rendelkező Hymenogaster nemzetség követte. A gyakorisági és a pozitív „co-occurence” vizsgálatok eredményei nagy részben összevethetők voltak egymással, a T. aestivum 
és két orchidea nemzetség, a Tuber brumale/Neottia, a H. griseus/Epipactis pozitív együttes előfordulása a gyakorisági százalékokban is megmutatkozik. Azonban voltak olyan orchidea/gomba párok, melyek a gyakorisági vizsgálatokban a 10\%-ot meghaladták, viszont a „co-occurence” vizsgálatok szerint az előfordulásuk véletlenszerü (pl. H. luteus/Cephalanthera, H. luteus/Epipactis, H. citrinus/ Epipactis). Ez utóbbi megállapítás alapján az a következtetés vonható le, hogy a gyakorisági vizsgálat önmagában két faj együttes előfordulásának elemzésére nem alkalmazható, mellette egyéb kiegészítő statisztikai módszer alkalmazása is szükséges.

Összegzésként megállapítható, hogy a hazai erdeinkben található orchideák jelezhetnek bizonyos föld alatti gombafajokat. A „,co-occurence” tábla alapján azonban az látható, hogy ezek a kapcsolatok nem fajspecifikusak, ugyanis egy orchideához több gombafaj és egy gombafajhoz is több orchidea nemzetség kapcsolódhat. Az együttes előfordulás orchideákkal néhány gasztronómiai, így gazdasági jelentőséggel bíró föld alatti gombafajra is vonatkozik (pl. T. aestivum, T. brumale). Ez utóbbi fajok napjainkban folyó kereskedelmi mennyiségben történő helytelen gyüjtésének tulajdonítható természetvédelmi károkozások, úgymint a védett és fokozottan védett növények károsítása, esetleges pusztítása, a talajszerkezet és a föld alatti gomba micélium károsítása már tárgyát képezi számos hatósági eljárásnak. Mindezek kiemelten fontossá teszik, hogy orchideás élőhelyeken is etikus és jogkövető szarvasgombagyüjtés történhessen, illetve a szarvasgomba gyüjtők hatósági jellegü elméleti és gyakorlati képzésében rendkívüli hangsúlyt kapjon a szarvasgombákat jelző növények, különösen az orchideák ismerete.

Köszönetnyilvánítás - Ezúton fejezzük ki köszönetünket Dr. Simon Tibornak, aki az élőhelyek társulásait meghatározta, továbbá köszönettel tartozunk a Debreceni Egyetemen dolgozó Dr. Molnár V. Attilának és kutatócsoportjának az ültetett nyarasok orchideás élőhelyeinek listájáért.

\section{Irodalomjegyzék}

Bidartondo, M. I., Burghardt, B., Gebauer, G., Bruns, T. D. \& Read, D. J. (2004): Changing partners in the dark: isotopic and molecular evidence of ectomycorrhizal liaisons between forest orchids and trees. - Proc. R. Soc. Lond. B. 271: 1799-1806. doi: https://doi.org/10.1098/rspb.2004.2807

Bratek, Z., Illyés, Z., Szegő, D. \& Vértényi, G. (2001): Az orchidea-típusú mikorrhiza képződésének és müködésének egyes kérdései. - Bot. Közlem. 88: 185-193.

Bulpitt, C. J. (2005): The uses and misuses of orchids in medicine. - Q. J. Med. 98: 625-631. doi: https://doi.org/10.1093/qjmed/hci094

Dearnaley, J. D. W. (2007): Further advances in orchid mycorrhizal research. - Mycorrhiza 17: 475-486. doi: https://doi.org/10.1007/s00572-007-0138-1 
Fay, M. F. (2016): Orchid conservation: Further links. - Ann. Bot. 118: 89-91. doi: https://doi. org/10.1093/aob/mcw147

Ghorbani, A., Gravendeel, B., Naghibi, F. \& Boer, H. (2014): Wild orchid tuber collection in Iran: A wake-up call for conservation. - Biodivers. Conserv. 23: 2749-2760. doi: https://doi.org/10.1007/ $\underline{\text { s10531-014-0746-y }}$

Merényi, Zs., Illyés, Z., Völcz, G. \& Bratek, Z. (2010): A database and its application for the development of truffle cultivation methods. - Österr. Z. Pilzk. 19: 239-244.

Molnár, V. A., Wilfried, V., Vidéki, R., Máté, A., Sulyok, J., Óvári, M., Mészáros, A., Tóth, I. Zs., Magos, G., Somlyai, L. \& Bauer, N. (2011): Magyarország orchideáinak bemutatása. - In: Molnár, V. A. (szerk.): Magyarország orchideáinak atlasza. Kossuth Kiadó, Budapest, pp. 186-429.

Ouanphanivanh, N., Illyés, Z., Rudnóy, Sz. \& Bratek, Z. (2007): Hazai Orchis militaris élőhelyek orchidea-mikorrhiza gombáinak vizsgálata. - Tájökológiai Lapok 5: 325-332.

Ouanphanivanh, N., Merényi, Zs., Orczán, Á. K., Bratek, Z., Szigeti, Z. \& Illyés, Z. (2008): Could orchids indicate truffle habitats? Mycorrhizal association between orchids and truffles. - Acta Biol. Szeged. 52: 229-232.

Pecoraro, L., Girlanda, M., Kull, T., Perini, C. \& Perotto, S. (2013): Fungi from the roots of the terrestrial photosynthetic orchid Himantoglossum adriaticum. - Pl. Ecol. Evol. 146: 145-152. doi: https://doi.org/10.5091/plecevo.2013.782

R Core Team (2013): R: A language and environment for statistical computing. R Foundation for Statistical Computing, Vienna. http://www.R-project.org/

Rasmussen, H. N. (1995): Properties of „dust” seeds. In: Rasmussen, H. N. (szerk.): Terrestrial orchids from seed to mycotrophic plant. Cambridge University Press. pp. 7-14.

Roy, M., Yagame, T., Yamato, M., Iwase, K., Heinz, C., Faccio, A. \& Selosse, M.-A. (2009): Ectomycorrhizal Inocybe species associate with the mycoheterotrophic orchid Epipogium aphyllum but not its asexual propagules. - Ann. Bot. 104: 595-610. doi: https://doi.org/10.1093/aob/ men269

Seaton, P. T., Hu, H., Perner, H. \& Pritchard, H. W. (2010): Ex Situ Conservation of Orchids in a Warming World. - Bot. Rev. 76: 193-203. doi: https://doi.org/10.1007/s12229-010-9048-6

Selosse, M.-A., Faccio, A., Scappaticci, G. \& Bonfante, P. (2004): Chlorophyllous and Achlorophyllous Specimens of Epipactis microphylla (Neottieae, Orchidaceae) Are Associated with Ectomycorrhizal Septomycetes, including Truffles. - Microb. Ecol. 47: 416-426. doi: https://doi. org/10.1007/s00248-003-2034-3 d

Smith, S. E. \& Read, D. J. (2010): Ericoid, orchid and mycoheterotrophic mycorrhizas. In: Smith, S. E. \& Read, D. J. (szerk.): Mycorrhizal symbiosis. Academic Press, Elsevier, pp. 387-522.

Veech, J. A. (2013): A probabilistic model for analysing species co-occurrence. - Global Ecol. Biogeogr. 22: 252-260. doi: https://doi.org/10.1111/j.1466-8238.2012.00789.x

Veech, J. A. (2014): The pairwise approach to analysing species co-occurrence. - J. Biogeogr. 41: 1029-1035. doi: https://doi.org/10.1111/jbi.12318 


\title{
The studying the co-occurrence of forest orchids and mushrooms with hypogeous fruiting bodies in the Carpathian basin
}

\author{
Lilla Bóna ${ }^{1}, Z_{\text {ssolt Merényi }{ }^{2} \text { and Zoltán Bratek }}^{1}$ \\ ${ }^{1}$ Eötvös Loránd University, Faculty of Science, Department of Plant Physiology and \\ Molecular Plant Biology H-1117 Budapest, Pázmány Péter lane 1/C, Hungary \\ ${ }^{2}$ Hungarian Academy of Sciences, Biological Research Centre, Institute of Biochemistry \\ Synthetic and Systems, Biology Unit H-6726 Szeged, Temesvári krt. 62, Hungary \\ e-mail:bonalillaaa@gmail.com
}

The family Orchidaceae abounds in endangered species, for this reason this family is significant for nature conservation. Additionally the members of this family are connected with many organisms, thus the protection of the symbionts and habitats of the orchids are the task of nature conservation. During our work we examined the correlation of the co-occurence of forest orchids and mushrooms producing hypogeous fruit bodies as based on our field experience this organisms are found often in same habitat. The co-occurence was tested with frequency and „co-occurence” analysis. Based on our results the true truffles (Tuber spp.), especially the sommer truffle (Tuber aestivum), occur most frequently in the same habitat as orchids, while co-occurrence statistic showed six positive orchid- mushrooms with hypogeous fruiting bodies connections. The co-occurence draws attention to the complying with the importance of the rules of truffle gathering, with wich the protection of the orchids and the mycelium of the mushroom can become reality.

Keywords: orchids, mushrooms with hypogeous fruiting bodies, orchid mycorrhiza, „co-occurence” 